\title{
Penerapan Video Pembelajaran Untuk Meningkatkan Hasil Belajar Matematika Kelas VII SMP Negeri 2 Kota Bengkulu

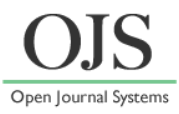

\author{
Aditya Rahmawati*, Hanifah \\ Program Studi Pendidikan Matematika JPMIPA FKIP Universitas Bengkulu \\ *adhitya.rahmawati06@gmail.com
}

DOI: https://doi.org/10.33369/pendipa.5.2.251-255

\begin{abstract}
This research aimed to improve student learning outcomes in mathematics by applying instructional videos. The type of research was classroom action research. The research subjects were students of class VII.A Junior High School (SMP) Negeri 2 Bengkulu academic year 2020/2021. The total subject was 36 students. The instrument was the final cycle concept comprehension test form. Based on the research results, the involvement in students learning outcomes seen from the average value of learning outcomes in cycle 1 and cycle 2 were 74.61 and 89.00 with the percentage of classical learning completeness of cycle 1 and cycle 2 were $61.11 \%$ and $69.44 \%$, respectively. Therefore, we conclude that the instructional video can improve the learning outcomes of students in learning mathematics
\end{abstract}

Keywords: mathematics learning; Learning Outcomes; Learning Videos.

\begin{abstract}
ABSTRAK
Penelitian ini bertujuan untuk meningkatkan hasil belajar peserta didik dalam pembelajaran matematika dengan menerapkan video pembelajaran. Jenis penelitian ini adalah penelitian tindakan kelas. Subjek penelitian yaitu peserta didik kelas VII.A SMP Negeri 2 Kota Bengkulu semester genap tahun ajaran 2020/2021 dengan jumlah 36 peserta didik. Instrumen yang digunakan adalah form tes kemampuan pemahaman konsep akhir sikslus. Berdasarkan hasil penelitian peningkatan hasil belajar peserta didik dapat dilihat dari nilai rata-rata tes hasil belajar siklus I dan siklus II yaitu 74,61 dan 89,00 dengan presentase ketuntasan belajar klasikal siklus I dan II yaitu 61,11 \% dan 69,44\%. Dari hasil penelitian ini dapat disimpulkan bahwa video pembelajaran dapat meningkatkan hasil belajar peserrta didik dalam pembelajaran Matematika.
\end{abstract}

Kata kunci: Pembelajaran Matematika; Hasil Belajar; Video Pembelajaran.

\section{PENDAHULUAN}

Pendidikan merupakan sebuah bentuk perwujudan kebudayaan manusia yang dinamis dan syarat perkembangan. Oleh karena itu, perubahan atau perkembangan pendidikan adalah hal yang seharusnya terjadi sejalan dengan perubahan budaya kehidupan. Menurut La Belle (dalam Ahmadi, 2014) pendidikan dipandang sebagai difusi sikap, informasi, dan keterampilan belajar yang diperoleh dari partisipasi sederhana dalam program-program yang berbasis masyarakat. Pendidikan diarahkan secara eksternal dan inisiatif sendiri (self-initiated) mengarah pada proses yang mana individuindividu belajar untuk fungsi kognitif, efektif dan psikomotorik dalam lingkungan mereka. Berdasarkan pada hal tersebut, pendidikan dapat dipahami sebagai serangkaian kegiatan interaksi manusia dengan lingkungannya yang dilakukan dengan sengaja dan terus menerus, dan sebagai hasilnya pendidikan menunjukkan pada hasil interaksi manusia dengan lingkungannya berupa perubahan dan peningkatan kognitif, efektif dan psikomotorik. Usaha untuk menciptakan sumber daya manusia yang berkualitas pastinya tidak terlepas dari upaya peningkatan kualitas pembelajaran pendidikan formal, dewasa ini menunjukkan masih rendahnya daya serap peserta didik. 
Matematika merupakan mata pelajaran yang sangat penting dalam kehidupan, baik di sekolah maupun kehidupan sehari-hari. Hal ini sejalan dengan pendapat Isrok'atun dan Rosmala (2018) bahwa matematika sebagai ratu dan pelayan ilmu lain, bahkan ilmu matematika digunakan sebagai pelayanan pengembangan ilmu pengetahuan lainnya. Pembelajaran matematika merupakan proses kegiatan belajar matematika untuk mengembangkan pengetahuan dan kreativitas peserta didik melalui interaksi antara pendidik dan peserta didik. Untuk mencapai kualitas pembelajaran matematika sesuai dengan apa yang diharapkan, maka diperlukan bahan ajar yang memadai saat melaksanakan proses pembelajaran matematika.

Sebagai upaya untuk mencegah pandemi Covid-19, pemerintah mengeluarkan kebijakan untuk meliburkan siswa dan mulai menerapkan metode belajar dengan sistem daring (dalam jaringan) atau online, hal ini sesuai dengan edaran Menteri Pendidikan dan Kebudayaan Republik Indonesia terkait Surat Edaran Nomor 4 Tahun 2020 tentang Pelaksanaan Kebijakan Pendidikan dalam Masa Darurat Penyebaran Corona Virus Disease (COVID-19) Sistem pembelajaran daring (dalam jaringan) merupakan sistem pembelajaran tanpa tatap muka secara langsung antara guru dan siswa tetapi dilakukan melalui online yang menggunakan jaringan internet. Guru harus memastikan kegiatan belajar mengajar tetap berjalan, meskipun siswa berada di rumah. Solusinya, guru dituntut dapat mendesain media pembelajaran sebagai inovasi dengan memanfaatkan media daring (online).

Dalam kenyataannnya, guru banyak yang belum memahami bagaimanan cara pelaksanaan pembelajaran dengan metode daring. Kebanyakan guru menggunakan apalikasi whatsapp, google classroom, google meet dan lain sebagainya hanya untuk mengintruksikan tugas yang harus dikerjakan siswa, seperti: "ringkaslah buku halaman sekian, baca buku halaman sekian dan kerjakan latihannya, kerjakan LKS dari halaman sekian sampai halaman sekian, dan lain sebagainya". Bagaimana siswa dapat menyelesaikan tugas, padahal materinya saja siswa tidak paham dan tidak terjadi interaksi dengan siswa. Hal ini yang akan membuat hasil belajar siswa rendah ketika guru memberikan evaluasi, terutama ditemukan pada mata pelajaran Matematika. Pada dasarnya objek pembelajaran matematika adalah abstrak. Materi pembelajaran diajarkan secara berjenjang atau bertahap, yaitu dari hal konkrit ke abstrak.

Dengan demikian guru dituntut mampu merancang dan mendesain pembelajaran daring yang ringan dan efektif, dengan memanfaatkan perangkat atau media daring yang tepat dan sesuai dengan materi yang diajarkan. Walaupun dengan pembelajaran daring akan memberikan kesempatan lebih luas dalam mengeksplorasi materi yang akan diajarkan, namun guru harus mampu memilih dan membatasi sejauh mana cakupan materinya dan aplikasi yang cocok pada materi dan metode belajar yang digunakan serta media belajar apa yang harus dipersiapkan.

Pemilihan media daring harus mampu mengakomodasi semua komponen yang ada dalam pembelajaran Matematika, yaitu adanya materi yang sesuai tujuan pembelajaran, metode pembelajaran yang sesuai, adanya forum diskusi, penugasan dan penilaian. Dalam pembelajaran Matematika juga harus menyediakan forum diskusi. forum diskusi bisa menggunakan media populer yang biasa digunakan yaitu whatshap atau Google Classroom.

Seperti pada penelitian Agus (2018) tentang Penerapan Pembelajaran Matematika Berbantuan Video Tutorial Untuk Meningkatkan Minat Dan Prestasi Belajar Matematika Siswa Kelas VIII D SMP Negeri 2 Sawan. Setelah diterapkan pembelajarab berrbantuan video tutorial dapat meningkatkan Minat Dan Prestasi Belajar Matematika Siswa, rata-rata skor minat belajar siswa dari 51,67 (kategori cukup positif) pada refleksi awal mengalami peningkatan menjadi 59,28 (kategori positif) pada siklus I, 64,71 (kategori sangat positif) pada siklus II, dan 66,53 (kategori sangat positif) pada siklus III. Rata rata skor minat belajar siswa pada siklus III berada pada kategori sangat positif. Untuk prestasi belajar matematika rata-rata skor prestasi belajar siswa dari 27,54 pada refleksi awal mengalami peningkatan menjadi 61,93 pada siklus I, 69,67 pada siklus II, dan 77,66 pada siklus III. Ini menunjukkan bahwa prestasi belajar siswa sudah memenuhi indikator keberhasilan, yaitu pada siklus III skor siswa memenuhi minimal KKM 70 dan $75 \%$ siswa berada pada kategori tuntas. 
Media video merupakan salah satu jenis media audio visual. Media audio visual adalah gabungan dari media audio (suara) dan visual gambar. Jadi, media audio visual adalah media yang mengandalkan pendengaran dan penglihatan. Media audiovisual merupakan salah satu media yang dapat digunakan dalam pembelajaran menyimak. Media ini dapat menambah minat siswa dalam belajar karena siswa bisa menyimak sekaligus melihat gambar. Media audio visual mengacu pada indera yang menjadi sasaran dalam sebuah media. Media audio visual mengandalkan pendengaran dan penglihatan dari sasaran (penonton).

Hamalik dalam Azhar mengemukakan bahwa keuntungan belajar dengan menggunakan media adalah "membangkitkan keinginan dan minat yang baru, membangkitkan motivasi dan rangsangan kegiatan belajar, dan bahkan membawa pengaruh-pengaruh psikologis terhadap siswa". Berdasarkan penjelasan tersebut kita tahu bahwa media pembelajaran mempunyai mafaat yang besar bagi guru dalam menyampaikan materi pembelajaran.

\section{METODE PENELITIAN}

Metode penelitian yang digunakan dalam penelitian ini adalah Penelitian Tindakan Kelas (PTK). Menurut Mulyasa (2009) penelitian tindakan kelas merupakan suatu upaya untuk mencermati kegiatan belajar sekelompok siswa dengan memberikan tindakan (treatment) yang sengaja dimunculkan. Tujuan penelitian ini adalah untuk meningkatkan hasil belajar peserta didik dalam pembelajaran matematika dengan menerapkan video pembelajaran. Penelitian ini dilaksanakan di SMP Negeri 2 Kota Bengkulu dengan Subjek kelas VII.A dengan jumlah 36 peserta didik tahun ajaran 2020/2021. Materi yang diambil saat penelitian dilakukan adalah materi himpunan. Penelitian ini dilaksanakan pada tanggal 16 Oktober 2020 sampai 20 November 2020 yang terdiri dari 4 Pertemuan. Instrumen pengumpulan data adalah form tes kemampuan pemahaman konsep akhir sikslus.

\section{HASIL DAN PEMBAHASAN}

Penelitian ini dilakasanakan dalam 2 siklus yaitu siklus I dan siklus II masing masing siklus ada 2 kali pertemuan. Tahap-tahap penelitian ini sedikit berbeda karena pembelajaran bukan dalam kelas atau pembelajaran secara klasikal melainkan secara terpisah atau siswa berada dirumah masing-masing.

Pembelajaran dilakukan dengan menggunakan media video pembelajaran yang di upload di youtobe kemudian dikirim melalu Whatsapp Grup kelas. Kegiatan yang dilakukan adalah guru membuka pelajaran melalui Whatsapp Grup dengan salam dan menanyakan kesiapan peserta didik untuk mengikuti pembelajaran, menyampaikan judul materi yang akan dipelajari, memotivasi peserta didik dan mengabsen peserta didik dengan mengirim link google form ke whatsapp grup, Setelah peserta didik mengisi absensi, guru mengirimkan video pembelajaran di whatsapp grup, meminta peserta didik untuk mengamati dan menyimak video pembelajaran dan membaca buku cetak matematika, mengidentifikasi hal yang belum dimengerti untuk ditanyakan, memberikan kesempatan kepada peserta didik untuk bertanya mengenai materi yang belum dimengerti dan dipahami, mengirimkan file soal LKPD Himpunan di whatsapp grup yang harus diselesaikan sesuai waktu yang telah ditentukan Selanjutnya guru beserta peserta didik membuat kesimpulan dari pembelajaran hari ini, guru memberi motivasi peserta didik agar rajin belajar, dan menutup pelajaran dengan salam melalui whatsapp grup.

Data hasil belajar pada siklus I dan II diperoleh dari tes formatif secara individual yang dilaksanakan setelah kegiatan siklus berakhir. Tes hasil belajar pada siklus I diikuti oleh 36 peserta didik dengan nilai rata-rata 74,61. Peserta didik yang mendapat nilai $\geq 72$ berjumlah 22 peserta didik atau sekitar $61,11 \%$. Ini berarti ada 14 peserta didik atau 38,89\% yang nilainya $<72$. Dengan demikian dapat dilihat bahwa: persentase peserta didik yang mendapatkan nilai $\geq 72$ sudah mencapai indikator yaitu $\geq 60 \%$ yaitu sebesar $61,11 \%$ dan rata-rata nilai peserta didik sudah cukup optimal.

Tes hasil belajar pada siklus II diikuti oleh 36 peserta didik dengan nilai rata-rata 89,00 . Peserta didik yang mendapat nilai $\geq 72$ berjumlah 25 peserta didik atau sekitar 69,44\%. Ini berarti ada 11 peserta didik atau 30,66\% yang nilainya $<72$. Dengan demikian dapat dilihat bahwa: persentase peserta didik yang 
mendapatkan nilai $\geq 72$ sudah mencapai indikator yaitu $\geq 60 \%$ dan rata-rata nilai peserta didik sudah optimal.

Hasil observasi untuk hasil belajar peserta didik pada siklus I dan Siklus II dapat dinyatakan dalam bentuk persentase sebagai berikut:

Tabel 1. Persentase dan Rata-rata Hasil Belajar Peserta didik yang Memperoleh Nilai $\geq 72$

\begin{tabular}{|c|c|c|c|}
\hline Siklus & $\begin{array}{c}\text { Jumlah } \\
\text { Peserta } \\
\text { didik }\end{array}$ & $\begin{array}{c}\text { Persentase } \\
(\%)\end{array}$ & Rata-rata \\
\hline I & 22 & $61,11 \%$ & 74,61 \\
\hline II & 25 & $69,44 \%$ & 89,00 \\
\hline
\end{tabular}

Berdasarkan data tersebut dan mengacu pada indikator keberhasilan pembelajaran maka dapat disimpulkan bahwa hasil belajar pada siklus I dan siklus II sudah mencapai tujuan yang diharapkan, yaitu $\geq 60 \%$ peserta didik mendapatkan nilai $\geq 72$.

Hasil refleksi menunjukkan bahwa, kegiatan pembelajaran daring dengan menggunakan media video pembelajaran mengalami sedikit kendala diantaranya ketika terjadi gangguan koneksi pada internetnya dan ada beberapa siswa yang tidak memiliki smartphone. Ada 4 orang anak yang tidak memiliki smartphone atau jika di persenkan sekitar $11,1 \%$ peserta didik yang tidak memiliki smartphone dan 32 siswa memiliki smartphone atau sekitar $88,9 \%$. Selain itu, dalam menyelesaikan soal evaluasi ada beberapa siswa masih bingung dalam mengidentifikasi masalah yang diberikan. Peneliti menyikapi hal ini dengan memberikan penambahan waktu batas pengumpulan soal sampai koneksi internet kembali stabil.

Oleh karena itu perlu adanya perbaikanPerbaikan tersebut meliputi: (1) Meningkatkan bimbingan kepada peserta didik dalam melaksanakan diskusi dan menyelesaikan tugastugas; (2) Memberikan contoh soal yang lebih variatif; (3) Membimbing bagaimana cara identifikasi masalah; (4) Memotivasi peserta didik untuk bertanya; (5) Memotivasi peserta didik untuk berani memberikan tanggapan; (6)
Memotivasi peserta didik untuk menjawab pertanyaan.

Pembelajaran daring dengan menggunakan media video pembelajaran ni sangat baik, hal ini ditunjukkan dengan adanya peningkatan hasil belajar sebesar $8,33 \%$ dari siklus I $61,11 \%$ menjadi $69,44 \%$ pada siklus II. Oleh karena itu perlu adanya perbaikan.

Grafik Nilai Rata-Rata dan Ketuntasan Belajar Klasikal

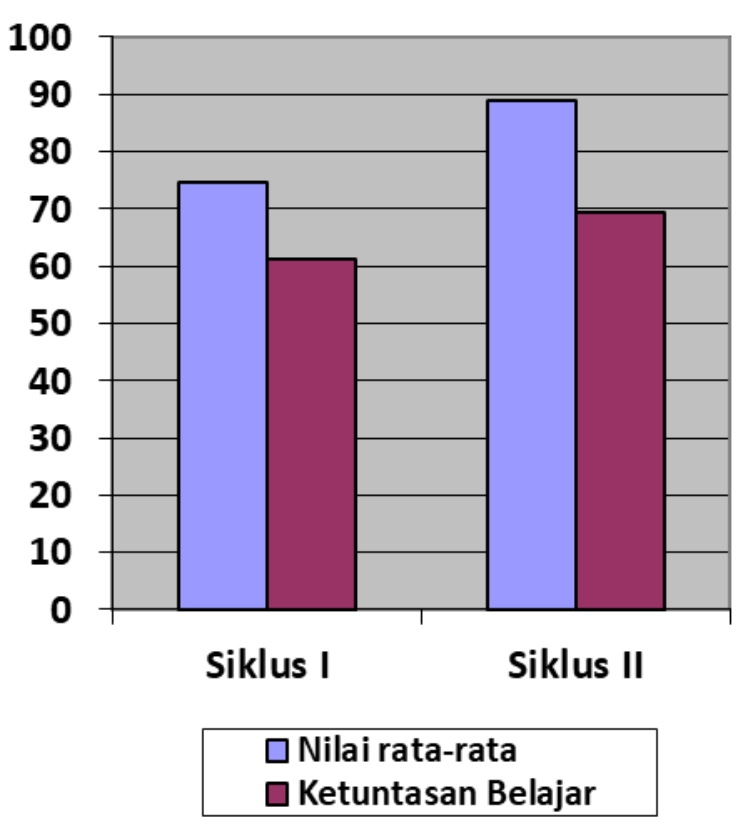

Grafik 1. Hasil Belajar Peserta Didik dan Ketuntasan Belajar Klasikal

Berdasarkan data tersebut menunjukkan bahwa pembelajaran daring dengan menggunakan media video pembelajaran dapat meningkatkan hasil peserta didik di kelas VII A SMP Negeri 2 Kota Bengkulu. Nilai hasil belajar peserta didik setiap siklusnya mengalami peningkatan. Peserta didik yang mengalami peningkatan hasil belajar adalah peserta didik yang aktif bertanya dan selalu menyimak dan memperhatikan video pembelajaran.

Tindakan yang dilakukan guru secara umum pada siklus I dan II untuk meningkatkan hasil belajar peserta didik yaitu mengingat materi sebelumnya sebelum masuk materi yang akan dipelajari, peserta didik diberikan motivasi sebelum memulai pembelajaran, peserta didik diberikan soal latihan sebanyak 5-10 soal dan dikerjakan secara individu untuk mempersiapkan diri melaksanakan tes akhir siklus. 
Analisi hasil belajar secara keseluruhan bahwa peserta didik menunjukkan secara umum hasil belajar mengalami peningkatan dari siklus I dan II. Sehingga Penerapan penggunaan video pembelajaran dapat meningkatkan hasil belajar peserta didik. Hal ini sesuai dengan pendapat Sudjana (2010). Melalui penggunaan video pembelajaran, guru diharapkan dapat mempertinggi kualitas proses belajar mengajar yang pada akhirnya dapat mempengaruhi kualitas hasil belajar siswa.

\section{KESIMPULAN DAN SARAN \\ Kesimpulan}

Penerapan Penggunaan video pembelajaran dapat meningkatkan hasil belajar peserta didik dengan cara: (1) mengingat materi sebelumnya sebelum masuk materi yang akan dipelajari; (2) peserta didik diberikan motivasi sebelum memulai pembelajaran; dan (3) peserta didik diberikan soal latihan sebanyak 5-10 soal secara individu pada akhir pembelajaran.

peningkatan hasil belajar sebesar $8,33 \%$ dari siklus I $61,11 \%$ menjadi $69,44 \%$ pada siklus II. Hal ini membuktikan bahwa hasil belajar peserta didik di kelas VII A SMP Negeri 2 Kota Bengkulu pada setiap siklus meningkat dengan menggunakan video pembelajaran..

\section{Saran}

Berdasarkan uraian dan pemaparan peneliti dapat memberikan saran sebagai berikut: (1) Bagi guru yang akan menggunakan video pembelajaran, sebaiknya guru harus memperhatikan waktu pembuatan video pembelajaran, karena pembuatan video memerlukan waktu yang relatif lama untuk benar benar layak ditampilkan ke peserta didik.
Sebaiknya penggunaan video pembelajaran ini juga dibarengi dengan penggunaan modul/buku paket agar peserta didik dapat benarbenar memahami materi pelajaran dengan baik; (2) Peserta didik dapat mempelajari pelajaran dengan melihat video yang telah dibuat dan dibagikan, namun agar peserta didik benar-benar bisa memahami sebaiknya memutar video tersebut secara berulang. Sebab tidak dipungkiri mungkin masih ada bagian-bagian pada video yang belum tergambarkan dengan jelas.

\section{DAFTAR PUSTAKA}

Abu, Ahmadi dan Widodo Supriyono. (2014) Psikologi Belajar. Jakarta: PT. Rineka Cipta.

Agus, Putu. (2018) Penerapan Pembelajaran Matematika Berbantuan Video Tutorial Untuk Meningkatkan Minat Dan Prestasi Belajar Matematika Siswa Kelas VIIID SMP Negeri 2 Sawan. Jurnal Pendidikan Matematika Undiksha. 9(2), 41-42.

Azhar, Arsyad. (2009). Media Pembelajaran. Jakarta: Raja Grafindo Persada Rineka Citra.

Isrok'atun dan Rosmala A. 2018. Model-model Pembelajaran Matematika. Jakarta: PT Bumi Aksara

Masdafni. (2020) Pembelajaran Daring Menggunakan Video Animasi Meningkatkan Hasil Belajar Matematika Siswa Kelas VIIC SMPN 1 Seberida. Jurnal Pendidikan Tambusai. 4(2), 1753-1754.

Mulyasa, E. (2009) Praktik Penelitian Tindakan Kelas. Bandung: PT. Remaja Rosdakarya.

Sudjana, N. dan Ahmad R. (2010) Media Pengajaran. Bandung: Sinar Baru Algensindo Offset. 